e-ISSN: 2622-3597. Available online at https://jurnal.umj.ac.id/index.php/ELIF

Peer-review under responsibility of Muhammadiyah University of Jakarta, Indonesia

\title{
The Effectiveness of Morphological Analysis Technique in Teaching Vocabulary
}

\author{
Ismalianing Eviyuliwati1), Dillan Kibar Dzikrika2), Bahrul Hasibuan3) \\ 1), 2) Universitas Islam Negeri Syarif Hidayatullah Jakarta, Tangerang Selatan, Banten, \\ Indonesia \\ 3) Universitas Muhammadiyah Prof. Dr. Hamka, Ciracas, Jakarta Timur, Indonesia \\ ismalianing.eviyuliwati@uinjkt.ac.id
}

\begin{abstract}
The purpose of the study was to investigate the effectiveness of Morphological Analysis technique in teaching vocabulary at SMPN 13 Kota Tangerang Selatan, Banten. The design of the study was quasi-experimental. The samples were 76 students of the 8th grade who were taken randomly using purposive random sampling. The samples were classified into two groups: 39 students in the experimental group and 37 in the control one. The data collected through a pretest and a posttest which had been proved valid and reliable by ANATES. In between, the teaching of 20 prefixes and 20 suffixes were done in both groups but with a higher frequency of occurrence in the experimental class. The finding showed that the experimental group got a higher mean score than the control one, and the statistical calculation found that there was a significant difference between the mean scores of the two groups. It indicated that the morphological analysis technique is effective to teach vocabulary to the $8^{\text {th }}$-grade students of SMPN 13 Kota Tangerang Selatan, Banten.
\end{abstract}

Keywords: morphological analysis, root, prefix, suffix

Citation APA Style: Eviyuliwati, I., Dzikrika, D. K., \& Hasibuan, B. (2018). The Effectiveness of Morphological Analysis Technique in Teaching Vocabulary. English Language in Focus (ELIF), 1(1), 9-22.

\section{INTRODUCTION}

$\mathrm{F}$ or many years vocabulary was seen as incidental to the main purpose of language teaching. Vocabulary was necessary for students but was frequently not the main focus for learning itself (Harmer, 1996, p. 154). Grammar teaching receives more attention rather than vocabulary teaching. However, Harmer states that recent linguists and methodologists focus their attention to vocabulary since vocabulary's acquisition is as important as grammar's acquisition. Moreover, during the 1980s, interest in vocabulary teaching and learning grew, and during the 1990s, a great deal of attention was given to vocabulary as a key component 
in L2 learning for successful communication (Chacón Beltrán et al., 2010, p. 1).

Vocabulary is one of the important components of language learning. With rich vocabulary, students can understand what is written on the text and convey meanings from it easily. It also can enhance students' ability to speak and express their feeling. Especially for non-native speakers, vocabulary has an important role to make them equal, or even surpass the native one in communicating (Chacón Beltrán, Abello-Contesse, \& TorreblancaLópez, 2010, p. 2). Therefore, vocabulary influences students' communication and their ability in using language skills. On the other hand, if a student has a limited vocabulary, he or she cannot comprehend what others utter, nor can he or she express his or her feeling through speaking. To avoid students facing those difficulties, the ability to use vocabulary must be the key to learning a language.

In fact, most students have difficulties in learning new vocabulary. Based on the writers' preliminary study in February 2016, the students' lack of vocabulary is caused by several reasons. One of them is students' lack of motivation in knowing the meaning of new words. When students face a new word, they usually depend on the teacher to tell them the meaning of the unknown words instead of looking it up from dictionaries. They are not triggered to know the meaning initiative and just left it unknown.

Moreover, the use of dictionary is not as effective as it should be. Students are not familiar with dictionary usage.
They spend a lot of time just to search for the meaning of a word. In addition, not all students bring dictionaries in the class and they just do nothing while waiting for their friends looking up a meaning of a word. The worst part is that some students even do not have any dictionary.

Hanson \& Padua (2011, p. 12) mention that students who are active in reading get many words incidentally, but students who read less do not. Unfortunately, a lot of students in need of vocabulary development do not engage in wide reading, especially of kinds of books or texts that contain unfamiliar vocabulary. These students are less able to convey meaningful information from the context. Students who are not spending time reading independently need to be taught explicitly to learn new words. Without the direct, in-depth teaching of keywords, most students will encounter difficulties comprehending what they read.

The way teachers teach vocabulary also has an impact on students' ability to use vocabulary. Many vocabulary instructions from high school to adult level employed memorization. Commonly, teachers teach vocabulary implicitly and just order students to list some challenging words in a textbook and look up their meaning in the dictionary then use the target words in the sentences (Allen, 2007, pp. 4-6). This makes students remember just a few of those words. In teaching vocabulary, selecting what words should be taught is really important. Although some syllabi would provide word list, there is no guarantee that the list for one student will be exactly similar to different students. So, Harmer proposes the 
general principle in vocabulary selection as following:

a. Frequency. The words which are most commonly used are the ones we should teach first.

b. Coverage. A word is more useful if it covers more things than if it only has one very specific meaning.

c. Choice. The decision about what vocabulary to teach and learn will be heavily influenced by information we can get about frequency and use. But this information will be assessed in the light of other consideration such as topic, function, structure, teaching ability, needs and wants (1996, pp. 154-156).

In addition, Gairns \& Redman state that there are four criteria for selecting vocabulary.

a. Frequency. The high frequency of an item is no guarantee of usefulness, but there is obviously a significant correlation between the two so it is worth examining some of the work on frequency word-counts that has been carried out over recent decades.

b. Cultural factors. The utterances of native speakers will obviously reflect the cultural interests of these speakers.

c. Need and level. Common sense dictates that students who learn English in their native country will have different lexical needs to those learners who want survival English for travel purposes in Englishspeaking countries.

d. Expediency. The classroom will often dictate the need for certain vocabulary, without which the students may fail to understand their teacher, fellow students or the activity they are supposedly engaged (1986, p. 58-64).

Chacon-Beltran et al., quoting Ellis, point out that there are two possibilities of processing new vocabulary: implicit and explicit vocabulary learning hypothesis (2010, pp. 3-4). An implicit vocabulary learning hypothesis means the meaning of the new word is acquired totally unconsciously as a result of repeated exposures in a range of activated context. On the other hand, explicit vocabulary learning hypothesis means giving explicit attention to the novel words by conscious and planned strategies such as noticing a new word, selectively attending to it and using a variety of strategies in order to convey its meaning from the context.

Teaching vocabulary implicitly through extensive reading provides more contextual learning and recycling words that have been learned, but seems too slow and unproductive in learning new vocabulary. On the other hand, teaching vocabulary explicitly is focused and effective but limited by the time in the classroom provided and the number of words that can be addressed.

Teachers, therefore, need another technique in teaching vocabulary. Teaching vocabulary explicitly is important and considered as one of the ways to overcome the problems. Morphological analysis or word formation is one of the techniques in teaching vocabulary explicitly.

Morphological analysis which means breaking an unfamiliar word into parts and then recombines them into a meaningful whole is believed to help 
students to discover many new words and to use it. For example, a student who knows the meaning of the word "believe" is considered to be able to understand the meaning of "believable" and "unbelievable" by analysing its morphemes. The morphological analysis will not happen if the students do not know the meaning of the root words and the affixes (White, Power, \& White, 1989, p. 284).

Morphological analysis technique is one of the ways to teach vocabulary explicitly. Morphological analysis is a technique to analyze unfamiliar word with the knowledge of morphology. White et al. define that morphological analysis is "to break an unfamiliar word into parts and then recombine them into a meaningful whole"(White et al., 1989, p. 284). Morphological analysis is also known as word formation or word-part clues.

Moreover, Anglin, Miller, \& Wakefield (1993, pp. 4-5) states that one could possibly figure out the meaning of morphologically complex words through knowledge of their corresponding root words and the rules of morphology and word formation. This knowledge is called morphological analysis and composition, or what Angling calls as morphological problem solving. Explicitly, he states that morphological analysis as "breaking complex words into and identifying the meanings of their morphological components".

Similar to the context clues technique, morphological analysis technique helps students to convey the meaning of unfamiliar words without opening dictionary. Context clues give students the word's meaning through analyzing the context of the sentence, while morphological analysis technique sees the unknown word itself to convey its meaning.

Morphological analysis is generally divided into three steps. The first step is to break unfamiliar words into parts, which are root and affixes. The next step is to identify those parts meaning. To identify the meanings, students need to have prior knowledge of each part. After knowing the meaning of each part, the final step is to recombine those parts into a new meaningful word.

To successfully complete the technique, morphological analysis requires three knowledge (White et al., 1989, p. 294).

1. Knowledge of prefixes and their meanings

2. Knowledge of suffixes and their meanings, including, perhaps, knowledge of associated changes in spelling and pronunciation

3. Knowledge of the meaning of the base or root word.

Words can be separated into pieces. These pieces are called morphemes. Katamba \& Stonham (2006, p. 24) defines, "Morpheme is the smallest difference in the shape of a word that correlates with the smallest difference in word or sentence meaning or in grammatical structure". In brief, morpheme is the smallest unit of the word that carries meaning. Morpheme is also known as word parts.

There are two types of morphemes: free morpheme and bound morpheme. Free morphemes are morphemes that can stand alone as a word, while bound morphemes are morphemes that cannot stand alone. Affix is a morpheme which 
only occurs when attached to some other morpheme or morphemes such as root or stem or base (Katamba \& Stonham, 2006, p. 44). In short, affix is a bound morpheme that cannot stand by its own. Affix which is selected for syntactic reason such as play-s, is called inflectional affix. On the other hand, derivational affix is an affix that changes a meaning of a word, or a word's classes such as play-er. Affixes are generally divided into three: prefix, suffix, and infix. Affix which precedes a word such as un-, re-, and dis-, etc. are called prefix. Suffix is an affix which follows at the end of a word, such as -ful, -ness, -ly, etc. Meanwhile, infix is rare in English. An affixed word can be developed by a prefix, or a suffix, or both.

The word that can be attached by affixes called base word. Lieber (2012) states "the base is a semantic core of the word to which the prefixes and suffixes attach" (p.33). In addition, Hanson and Padua define that base word is the smallest group of letters that form a complete word.

On the other hand, root word is a special kind of base word. Like a base word, it carries the main part of a word's meaning, but some of them need a prefix or suffix to form a complete word in English. Many roots come from Greek or Latin. For example, struct is a root word that means "build or form". However, struct cannot stand alone as a word. To make it a word, affixes must be attached, for example, construction, destruction (Hanson \& Padua, 2011, p. 18).

There is no firm answer to decide which prefixes and suffixes should be taught. However, frequency is one of important factors that we must consider in selecting affixes. The followings (Table 1 and Table 2) are the list of prefixes and suffixes that have high frequency in the Word Frequency Book (White, Sowell, \& Yanagihara, 1987, pp. 303-304).

Table 1. The most common prefixes in printed school English for grades 3-9

\begin{tabular}{|c|c|c|c|}
\hline Rank & Prefix & $\begin{array}{c}\text { Number of } \\
\text { different } \\
\text { words with } \\
\text { the prefix* }\end{array}$ & $\begin{array}{c}\text { Percentag } \\
\text { e }\end{array}$ \\
\hline 1. & un- & 782 & 26 \\
\hline 2. & re- & 401 & 14 \\
\hline 3. & $\begin{array}{l}\text { in-, im-, } \\
\text { ir-, il-, } \\
\text { 'not' }\end{array}$ & 313 & 11 \\
\hline 4. & dis- & 216 & 7 \\
\hline 5. & en-, em- & 132 & 4 \\
\hline 6. & non- & 126 & 4 \\
\hline 7. & $\begin{array}{l}\text { in-, im-, } \\
\text { 'in or } \\
\text { into' }\end{array}$ & 105 & 4 \\
\hline 8. & $\begin{array}{l}\text { over- } \\
\text { 'too } \\
\text { much' }\end{array}$ & 98 & 3 \\
\hline 9. & Mis- & 83 & 3 \\
\hline 10. & $\begin{array}{l}\text { Over- } \\
\text { 'too } \\
\text { much' }\end{array}$ & 80 & 3 \\
\hline 11. & Pre- & 79 & 3 \\
\hline 12. & Inter- & 77 & 3 \\
\hline 13. & Fore- & 76 & 3 \\
\hline 14. & De- & 71 & 2 \\
\hline 15. & Trans- & 47 & 2 \\
\hline 16. & Super- & 43 & 1 \\
\hline 17. & Semi- & 39 & 1 \\
\hline 18. & Anti- & 33 & 1 \\
\hline 19. & Mid- & 33 & 1 \\
\hline 20. & $\begin{array}{l}\text { Under- } \\
\text { 'too litle' }\end{array}$ & 25 & 1 \\
\hline $\begin{array}{c}\text { Tota } \\
1\end{array}$ & $\begin{array}{c}\text { All } \\
\text { other } \\
\text { s }\end{array}$ & 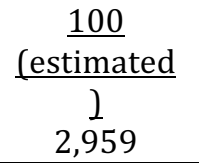 & $\underline{3}$ \\
\hline
\end{tabular}

* From John B. Carroll, Peter Davies, and Barry Richman, the American Heritage Word Frequency Book, Boston, MA: Houghton Mifflin, 1971 
Table 2. English suffixes ranked by frequency of occurrences

\begin{tabular}{|c|c|c|c|}
\hline $\begin{array}{c}\operatorname{Ran} \\
\mathbf{k}\end{array}$ & Suffix & $\begin{array}{l}\text { Number of } \\
\text { occurrence } \\
\text { s in sample }\end{array}$ & $\begin{array}{c}\text { Percentag } \\
\mathbf{e}\end{array}$ \\
\hline 1. & $-s,-e s$ & 673 & 31 \\
\hline 2. & -ed & 435 & 20 \\
\hline 3. & -ing & 303 & 14 \\
\hline 4. & -ly & 144 & 7 \\
\hline 5. & $\begin{array}{l}\text {-er, -or } \\
\text { (agentive) }\end{array}$ & 95 & 4 \\
\hline 6. & $\begin{array}{l}\text {-ion, -tion, - } \\
\text { ation, } \\
\text {-ition }\end{array}$ & 76 & 4 \\
\hline 7. & -ible, -able & 33 & 2 \\
\hline 8. & -al, -ial & 30 & 1 \\
\hline 9. & $-\mathrm{y}$ & 27 & 1 \\
\hline 10. & -ness & 26 & 1 \\
\hline 11. & -ity,- ty & 23 & 1 \\
\hline 12. & -ment & 21 & 1 \\
\hline 13. & -ic & 18 & 1 \\
\hline 14. & $\begin{array}{l}\text {-ous, -eous, - } \\
\text { ious }\end{array}$ & 18 & 1 \\
\hline 15. & -en & 15 & 1 \\
\hline 16. & $\begin{array}{l}\text {-er } \\
\text { (comparativ } \\
\text { e) }\end{array}$ & 15 & 1 \\
\hline 17. & $\begin{array}{l}\text {-ive, -ative, - } \\
\text { itive }\end{array}$ & 15 & 1 \\
\hline 18. & -ful & 14 & 1 \\
\hline 19. & -less & 14 & 1 \\
\hline 20. & -est & 12 & 1 \\
\hline $\begin{array}{c}\text { Tota } \\
\text { l }\end{array}$ & All others & $\frac{160}{2,167}$ & $\begin{array}{c}\underline{7} \\
100 \%\end{array}$ \\
\hline
\end{tabular}

The sample consisted of the 2,167 suffixed words appearing on 60 randomly, selected pages in John B. Carroll, Peter Davies, and Barry Richman, The American Heritage Word Frequency Book, Boston, MA: Houghton Mifflin, 1971

* The total actually exceeds $100 \%$ due to rounding upward on items in ranks 1320.

In doing morphological analysis, one undergoes a process that explained in the model proposed by White et al (1989, pp. 293-294) at (Fig. 1).

Stage 0: Student who is reading along in a text does not engage in morphological analysis unless two conditions are met. First, he or she must have encountered an unfamiliar word. Second, the student must be motivated to discover the meaning of the unfamiliar word.

Stage 1: The reader initially looks for and removes the prefix, if any; otherwise, he or she looks for a suffix and removes it. The reader then determines the meaning of the affix, from memory if it is a prefix or with the help of context if it is a suffix.

Stage 2: The reader looks at the remaining base word, and tries to retrieve its meaning from semantic memory using available context cues.

Stage 3: Finally, the reader combines the meaning of the base word with the meaning of the affixes.

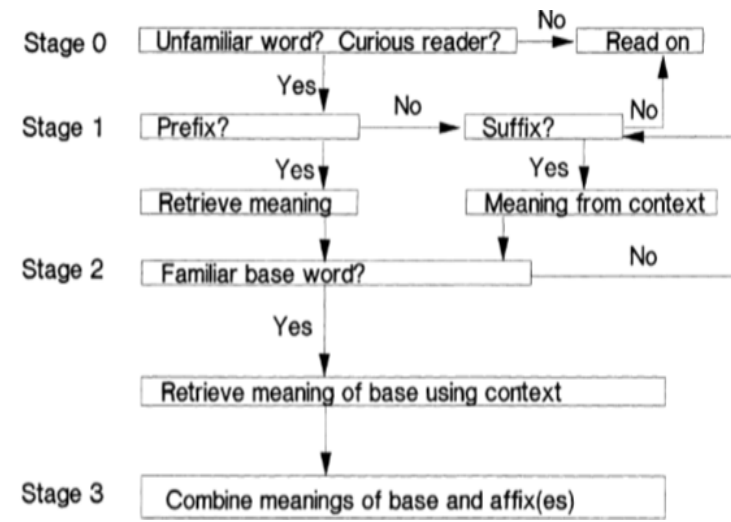

Figure 1. Flowchart Representing the Model of Morphological Analysis

Knowing the definition and the usage of affixes, both prefix and suffix, is 
very important in doing morphological analysis in order to know the meaning of unfamiliar words that impact students' ability to use the vocabulary. As in the Wysocki \& Jenkins's study, the participants who are 4th, 6th, and 8th grade students succeed in deriving the meaning of unfamiliar words with affection of prior experience with related words (1987, pp. 66-81). This study shows that morphological analysis knowledge affects the students' vocabulary size.

Based on the explanation above, the writers assume that morphological analysis is more effective than conventional way of teaching vocabulary. Thus, the writers would like to conduct a research to answer the research question: "Is Morphological Analysis technique effective to teach vocabulary at the eighth grade students of SMPN 13 Tangerang Selatan?"

\section{RESEARCH METHODOLOGY}

he research used quantitative
method and quasi-experimental
design. The population of the study was eighth grade students of SMP Negeri 13 Kota Tangerang Selatan. They were divided into eight classes, 8.1 to 8.8 , with approximately 40 students in each class. The total numbers of the students therefore were 307 students. Using purposive random sampling technique, two classes of them (classes 8.7 and 8.8) were taken as the sample. Class 8.8 was assigned to be the experimental group and class 8.7 was the controlled group.

The instruments used to collect the data were tests and interview. The first tests were in the form of pretests, which were given to both classes before the treatments given. While the other tests were the posttests, which were given to the sample after the four-time treatments. Before used as the research instruments, the pretest and post-test items had been proved valid and reliable through ANATES. The validity values of the pretest and posttest were 0.85 and 0.71 . While, the reliability values of pretest and posttest were 0.92 and 0.83 , respectively.

Furthermore, the analysis techniques for the data from tests were normality test, homogeneity test, and ttest. To do all those analyses, the writers employed IBM SPSS version 22. While the data from interview were analyzed according to the students' level of the scores, i.e. low, mid, or high scores.

Finally, the writers proposed two hypotheses as follows:

Ho : Morphological analysis technique was not effective to teach vocabulary at eighth grade students of SMP Negeri 13 Kota Tangerang Selatan.

Ha : Morphological analysis technique was effective to teach vocabulary at eighth grade students of SMP Negeri 13 Kota Tangerang Selatan.

\section{FINDING AND DISCUSSION}

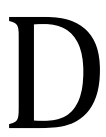
ata Description

The experimental group in this research was 39 students in class 8.8 at SMPN 13 Kota Tangerang Selatan. At first, they were given a pretest in the form of multiple-choice test of vocabulary. It was given to know their vocabulary knowledge before the treatments were given. The finding showed that the pretest mean score was 54.46. In addition, the lowest score in the pretest was 36 , while the highest score in 
the pretest was 68. After the pretest, in the next four meetings, the students were taught reading comprehensions, in which to comprehend the texts the students need to understand the meaning of the vocabulary used in the texts.

To make the students know the meanings of the vocabulary, the writers explained the vocabulary explicitly using Morphological Analysis technique. In the teaching processes, the writers introduced 20 English prefixes and 20 English suffixes taken from Table 1 and Table 2. After the treatments, the posttest was conducted. The finding revealed that the mean score was increased to 72.31. In addition, the lowest score in the posttest was 56 , while the highest score in the posttest was 92 . It showed that the students' post-test mean score was higher than that of the pretest. The gain between the pretest mean score and posttest mean score was 17.85 points.

On the other hand, class 8.7, which consisted of 37 students, was assigned to be the controlled group. A pretest was also given to this group and the mean score was 54.92. In addition, the lowest score in the pretest was 36, while the highest score was 68 . After the pretest, the students in this group were also taught reading comprehensions in the next four meetings, but having no discussions on the vocabulary explicitly using morphological analysis technique like one in the experimental group. Rather, they learned reading comprehension without any explicit discussion on the difficult vocabulary. After that, the posttest was also given and the mean score was 66.59. In addition, the lowest score in the posttest was 52 , while the highest score was 88 . The scores therefore were also increased but the gain score was only 11.67.

The data of both the experimental and the controlled groups are presented in the following table.

Table 3. The Descriptive Data of the Experimental and Controlled Groups

\begin{tabular}{l|c|c|c|c}
\hline \multirow{2}{*}{} & \multicolumn{2}{|c|}{ Experimental Class } & \multicolumn{2}{c}{ Controlled Class } \\
\cline { 2 - 5 } & Pretest & Posttest & Pretest & Posttest \\
\hline Mean & 54.46 & 72.31 & 54.92 & 66.59 \\
\hline Median & 56 & 72 & 56 & 64 \\
\hline Modus & 56 & 68 & 56 & 64 \\
\hline Minimum & 36 & 56 & 46 & 52 \\
\hline Maximum & 68 & 92 & 68 & 88 \\
\hline Sum & 2124 & 2820 & 2032 & 2464 \\
\hline
\end{tabular}

From Table 3, it can be seen that in the pretests, the experimental group's mean score (54.46) was lower than that of the controlled one (54.92). However, after given the treatments, the mean score of the experimental group (72.31) became higher than that of the controlled one (66.59). Moreover, the highest score in the experimental group's post-test (92) was also higher than that of the controlled one (88).

After giving the posttests, the writers also conducted interviews to 24 students, 12 students from the experimental class and 12 students from the controlled one. The participants were chosen based on their posttest scores which were divided into three categories: High, Mid, and Low scores. Each category was fulfilled by 4 students. 
All participants were asked to look at their posttest answers and given two questions:

1. What was your answer?

2. Why did you choose it? Please explain your reason.

The participants were asked to mention their ten answers out of twenty five posttest questions, then they had to explain why they chose it.

After interviewing the participants, the writers transcribed students' response, then categorized the responds into 4 categories: with clear explanation, with explanation but chose the wrong answer, with insufficient or incorrect explanation, and no explanation.

The first category was with clear explanation. This meant that the students chose the correct answer and could give the correct explanation related to the question. For instance, if a student could explain that "rewrite" was developed by prefix "re-" that meant "to do again" and a root word "write", it was categorized as with clear explanation. The second category was with explanation but chose the wrong answer meant that the students explained the meaning of the unfamiliar word well, but unfortunately chose the wrong answer. For example, the student with code Exp.Low.001 (see Table 4) explained that "unhappy" meant "not happy", but he chose "very happy" as his answer instead. The next category was with insufficient or incorrect explanation. This category meant that the students chose the correct answer but did not explain the reason sufficiently or they explained the wrong meaning of an affix. For instance, student with code Ctr.Low.003 explained that "nonstop" meant "without stopping", but without any further explanation. That was considered as insufficient explanation. On the other hand, student with code Exp.High.002 explained that "talkative" meant "speak a lot" because the word was constructed by "talk" and "active", was considered as incorrect explanation. The last category was no explanation, which meant that the students could not give any reasons related to their answers. Table 4 below contained how many questions that the students could/could not explain based on their response in the interviews.

Table 4. Data from Interview

\begin{tabular}{l|c|c|c|c}
\hline \multirow{2}{*}{ Student' Code } & \multicolumn{4}{|c}{ Item(s)/Question(s) } \\
\cline { 2 - 5 } & $\begin{array}{c}\text { With clear } \\
\text { explanation }\end{array}$ & $\begin{array}{c}\text { With } \\
\text { explanation } \\
\text { but chose the } \\
\text { wrong answer }\end{array}$ & $\begin{array}{c}\text { With } \\
\text { insufficient or } \\
\text { incorrect } \\
\text { explanation }\end{array}$ & $\begin{array}{c}\text { No } \\
\text { explanation }\end{array}$ \\
\hline Exp.High.001 & 8 & 0 & 1 & 1 \\
\hline Exp.High.002 & 6 & 0 & 1 & 2 \\
\hline Exp.High.003 & 3 & 0 & 1 & 6 \\
\hline Exp.High.004 & 5 & 1 & 0 & 4 \\
\hline Exp.Mid.001 & 7 & 0 & 1 & 2 \\
\hline Exp.Mid.002 & 1 & 0 & 0 & 9 \\
\hline Exp.Mid.003 & 1 & 0 & 1 & 8 \\
\hline Exp.Mid.004 & 9 & 0 & 1 & 0 \\
\hline Exp.Low.001 & 1 & 2 & 2 & 5 \\
\hline Exp.Low.002 & 0 & 0 & 0 & 10 \\
\hline Exp.Low.003 & 2 & 1 & 0 & 7 \\
\hline Exp.Low.004 & 0 & 0 & 0 & 10 \\
\hline Ctr.High.001 & 5 & 0 & 3 & 2 \\
\hline Ctr.High.002 & 6 & 0 & 3 & 1 \\
\hline Ctr.High.003 & 5 & 0 & 2 & 3 \\
\hline Ctr.High.004 & 1 & 0 & 0 & 9 \\
\hline Ctr.Mid.001 & 0 & 1 & 1 & 8 \\
\hline Ctr.Mid.002 & 0 & 0 & 0 & 10 \\
\hline Ctr.Mid.003 & 0 & 0 & 0 & 10 \\
\hline Ctr.Mid.004 & 2 & 0 & 0 & 8 \\
\hline Ctr.Low.001 & 0 & 0 & 0 & 10 \\
\hline Ctr.Low.002 & 0 & 0 & 0 & 10 \\
\hline Ctr.Low.003 & 2 & 0 & 2 & 6 \\
\hline Ctr.Low.004 & 0 & 0 & 0 & 10 \\
\hline & & & & 1 \\
\hline
\end{tabular}

\section{Data Analysis}

The Analysis of Data from Tests. First of all, the normality test was done to both the pretest and posttest data to see whether the data were normally distributed or not. Based on the criteria 
of normality hypothesis, if the significance level or probability value $>$ the degree of significance ( $\alpha=0.05$ ), the data were distributed normally. On the other hand, if the significance level or probability value < the degree of significance $(\alpha=0.05)$, then the data were not distributed normally. The result explained that the significance level or probability value (p) of the pretest scores in the experimental class was 0.135 and in the controlled class was 0.081. In addition, the significance level or probability value ( $\mathrm{p}$ ) of posttest scores in the experimental class was 0.238 and in the controlled class was 0.081 . Thus, the result of normality test proved that the significance level or the probability value (p) was higher than ( $>$ ) the degree of significance ( $\alpha=0.05)$. It indicated that the data of the pretests and posttests of both experimental and controlled classes were normally distributed.

Furthermore, to calculate the homogeneity test, the writers used Levene Statistic Test from IBM SPSS Statistics 22 software, too. The result revealed that the significance level (Sig.) from pretest was 0.689 and the significance level (Sig.) from posttest was 0.679. It meant that the significance level of the data was higher than the degree of significance $(\alpha=0.05)$. Based on the criteria of homogeneity hypothesis, if the significance level or probability value > the degree of significance $(\alpha=0.05)$, then the sample data had homogenous variance. In contrast, if the significance level or probability value $<$ the degree of significance $(\alpha=0.05)$, then the sample data did not have homogenous variance. Therefore, it could be interpreted that the pretest and posttest sample data had homogenous variance from the population they were taken. Therefore, the study revealed that the probability values of the pretest and posttest data were higher than 0.05 . It meant that the sample data of the study had homogenous variance from the population.

Finally, the hypotheses testing was conducted to see whether there was significant difference in the result of posttests after the treatments were given. The writers used the value of $5 \%$ or 0.05 as the significance value $(\alpha)$ of the study. The result showed that the value of tcount was 2.596. The df (Degree of Freedom) was taken from the total number of students minus (-) 2, so the $\mathrm{df}$ was 74 because the total number of the students of both classes was 76 . Furthermore, sig. 2 tailed or (p) value was 0.011. Based on the result, it explained that sig. 2 tailed value (p) was smaller than $\alpha(p<\alpha) ;(0.011<0.05)$. It meant that there was a significant difference between the mean score of posttest of the experimental and controlled classes. The result also showed that tcount was 2.596 and ttable with df 74 and $\alpha 0.05$ is 1.666. Because tcount was greater than ttable (2.596 > 1.666), it was considered that $\mathrm{HO}$ was rejected and Ha was accepted. In other words, morphological analysis technique was effective to use in teaching vocabulary at the eighth grade students of SMP Negeri 13 Kota Tangerang Selatan.

The Analysis of Data from Interview. Based on the data description of interview, there was a significant difference between the experimental class students' responds and those of the 
controlled class. In the controlled class, there were 5 students who could not give any reason why they chose their answers. When they were asked to explain their reasons, the common response were "I only guessed the answer". This meant that they really did not know what the meaning of the unfamiliar words was. Meanwhile, in the experimental class, there were only 2 students from Low score category who answered all of the ten questions by guessing. In addition, students with high and mid scores in the experimental class tended to have more correct explanation rather than students in controlled class. It could be seen that even students with mid scores could explain 7 up to 9 reasons of their answer choices, while students with mid score in the controlled class could not. Surprisingly, students with high scores in the controlled class could answer the questions well, but they could not give sufficient explanations or even give incorrect reasons. For instance, student with code Ctr.High.001 said that he knew the meaning of "disbelieve" because he knew the meaning of "dislike", and simply explained that "nonstop" meant "without stopping" with no further explanation. Student with code Ctr.High.002 explained that "overacting" meant "not to react" because she thought that "over" meant "not", and she chose "talkative" meant "speak a lot" because she considered that the other choices were not correct. Then, Ctr.High.003 stated that "un" from "unhappy" was a verb, "hotter" was from "hot" but could not explained that "-er" indicated the comparative form of an adjective, and repeatedly said that he knew the meaning of the unfamiliar words but could not give any explanation.

\section{Discussion}

From the research findings above, it indicated that the students in the experimental class obtained better scores in the posttest than students in the controlled class. It could be seen from the result of mean scores of both classes. The mean score of posttest in the experimental class was 72.31 while the mean score of posttest in the controlled class was 66.59. Therefore, the mean score of posttest of the experimental class was higher than that of the controlled class. Moreover, there were increasing points of the mean score in the experimental class. The mean score of the experimental class increased 17.85 points; from 54.46 in the pretest to 72.31 in the posttest.

In t-test analysis, if tcount $<$ ttable, it meant that $\mathrm{HO}$ was accepted and $\mathrm{Ha}$ was rejected. On the other hand, if tcount $>$ ttable, it meant that $\mathrm{HO}$ was rejected and Ha was accepted. The result showed that tcount value was 2.596 while ttable with degree of freedom 74 and degree of significance 0.05 was 1.666 . It meant that the tcount was greater than ttable. It indicated that morphological analysis technique is effective to teach vocabulary.

Having had the above findings, the writers believed that morphological analysis technique had helped students in increasing their vocabulary knowledge. Students who had known the morphological analysis technique could collaborate a word and certain affixes then conveyed meaning from it without opening dictionary. For instance, if a 
student knew the root or base human and its meaning, he or she could convey meaning from words such as superhuman, humanity, and humanly. Also if he or she knew the meaning of affix super, he or she would easily convey the meaning of words such as supermodel, superstar, and supermarket.

Thus, teaching vocabulary explicitly is more effective than using conventional way such as word list or memorizing. With teaching vocabulary explicitly, students learn a lot of new vocabulary and its meaning consciously. Hanson \& Padua (2011) also stated that the teaching of morphology and word formation explicitly are seen effective to increase students' ability to use vocabulary. In addition, with morphological analysis technique, students could recognize synonyms of words such as sad with unhappy, dirty with unclean, and open with unlock. Even based on the interview, students with Low score in the experimental class could give meaning and explanation of unfamiliar words better than students who did not receive any morphological analysis technique. Therefore, instruction in morphology should occur at every grade level.

To sum up, morphological analysis technique could be one of effective techniques in teaching vocabulary. It taught students to look for the meaning of unfamiliar word by analysing its word-parts without opening dictionary. By teaching vocabulary explicitly, especially with morphological analysis technique, students consciously learnt new words without looking up the dictionary, but by analysing those unfamiliar words morphologically.

\section{CONCLUSION}

$\mathrm{V}$ ocabulary is one of the important keys to learn a language. However, students sometimes face difficulties in learning unfamiliar words and teachers do not give much attention to the vocabulary's instruction. Based on the findings of the study, one of the ways to overcome the problem is to teach vocabulary explicitly, i.e. through morphological analysis technique. Therefore, it can be concluded that morphological analysis technique is effective to teach vocabulary at the eighth grade students of SMP Negeri 13 Kota Tangerang Selatan. It helps the students to convey meaning of unfamiliar word from parts of the word itself without opening a dictionary. The conclusion above is supported by the data in which they were analyzed by using IBM SPSS Statistics 22 program. The data explained that the mean score of the experimental class increased 17.85 points; from 54.46 to 72.31 . In brief, the experimental class had higher mean score than the controlled class after the treatments were given. Based on the hypotheses testing, it showed that sig. 2 tailed values ( $\mathrm{p}$ ) was smaller than $\alpha$ ( $\mathrm{p}<$ $\alpha) ;(0.011<0.05)$. It indicated that there was a significant difference between the mean score of the experimental and controlled classes. The result showed that tcount value was greater than ttable with degree of freedom (df) 74 and degree of significance $(\alpha) 0.05$ or $(2.596$ $>1.666)$. Therefore, $\mathrm{H} 0$ was rejected and Ha was accepted. In brief, it proves that morphological analysis technique is effective to teach vocabulary at the 
eighth grade students of SMP Negeri 13

Kota Tangerang Selatan.

\section{REFERENCES}

Allen, J. (2007). Inside Words: Tools for Teaching Academic Vocabulary, Grades 4-12. Portland: Stenhouse Publishers.

Anglin, J. M., Miller, G. A., \& Wakefield, P. C. (1993). Vocabulary Development: A Morphological Analysis. Monographs of the Society for Research in Child Development, 58(10), $1-186$. https://doi.org/10.2307/1166112

Chacón Beltrán, R., Abello-Contesse, C., \& Torreblanca-López, M. del M. (2010). Insights into Non-Native Vocabulary Teaching and Learning. Bristol: Multilingual Matters.

Gairns, R., \& Redman, S. (1986). Working with Words : A Guide to Teaching and Learning Vocabulary. Cambridge: Cambridge University Press.

Hanson, S., \& Padua, J. F. M. (2011). Teaching Vocabulary Explicitly. Mariana: Pacific Resources for Education and Learning.
Harmer, J. (1996). The Practice of English Language Teaching. New York: Longman.

Katamba, F., \& Stonham, J. T. (2006). Morphology. Hampshire: Palgrave Macmillan.

Lieber, R. (2012). Introducing Morphology. Cambridge: Cambridge University Press. https://doi.org/10.1017/cbo97805 11808845

White, T. G., Power, M. A., \& White, S. (1989). Morphological Analysis: Implications for Teaching and Understanding Vocabulary Growth. Reading Research Quarterly, 24(3), 283-304. https://doi.org/10.2307/747771

White, T. G., Sowell, J., \& Yanagihara, A. (1987). Teaching Elementary Students to Use Word-Part Clues. The Reading Teacher, 42, 302-308. https://doi.org/10.2307/20200115

Wysocki, K., \& Jenkins, J. R. (1987). Deriving Word Meanings through Morphological Generalization. Reading Research Quarterly, 22(1), 66-81.

https://doi.org/10.2307/747721 
English Language in Focus (ELIF), 1 (1), 9-22. https://jurnal.umj.ac.id/index.php/ELIF 